\title{
PENCEGAHAN DAN PERAWATAN KARIES RAMPAN
}

\author{
Ni Wayan Mariati \\ Program Studi Pendidikan Dokter Gigi Fakultas Kedokteran \\ Universitas Sam Ratulangi Manado \\ Email: niwayan.mariati07@gmail.com
}

\begin{abstract}
Rampant caries is a common tooth problem found among children under five years old. The occurence of rampant caries can cause various problems mainly related to the general health of children who are in the growth period. Rampant caries is caused inter alia by lack of oral hygiene, poor dental structure, presence of high bacterial activity caries, frequent consumption of cariogenic foods and drinks, as well as time that influences the growing of rampant caries. Concerning the prevention of rampant caries, it is advisable to avoid all the factors mentioned above, and maintain the preventive and continuous care of oral health.
\end{abstract}

Keywords: rampant caries, multifactorial disease, children

\begin{abstract}
Abstrak: Karies rampan merupakan masalah yang sering ditemukan pada anak usia balita. Adanya karies rampan dapat menyebabkan berbagai masalah terutama yang berhubungan dengan kesehatan umum anak yang sedang dalam masa pertumbuhan. Karies rampan merupakan penyakit multifaktorial dengan faktor penyebabnya antara lain: kurangnya kebersihan mulut, struktur gigi yang kurang baik, adanya aktifitas bakteri karies yang tinggi, sering mengonsumsi makanan dan minuman kariogenik, serta waktu yang memengaruhi terjadinya karies rampan. Untuk menghindari terjadinya karies rampan dianjurkan untuk menghindari hal-hal tersebut di atas serta melakukan pencegahan dan perawatan secara berkesinambungan agar kesehatan gigi dan mulut dapat terjaga dengan baik.
\end{abstract}

Kata kunci: karies rampan, penyakit multifaktorial, anak-anak

Karies merupakan proses patologik berupa kerusakan pada jaringan keras gigi dimulai dari email, dentin, dan sementum yang disebabkan oleh aktivitas jasad renik dalam karbohidrat yang dapat diragikan. Karakteristiknya ialah terjadi demineralisasi jaringan keras gigi yang kemudian diikuti oleh kerusakan bahan organik. ${ }^{1}$

Karies dapat mengenai gigi sulung dan gigi tetap, namun proses kerusakan gigi sulung lebih cepat menyebar dan lebih parah dibanding gigi tetap. Faktor penyebab adanya perbedaan ini ialah karena struktur email gigi susu kurang padat dan lebih tipis dibanding gigi tetap. ${ }^{1}$

Karies yang sering dijumpai pada anak-anak ialah karies rampan. Ciri-ciri khas karies rampan yaitu terjadinya sangat cepat bila dibandingkan karies gigi umumnya, penyebarannya mengenai beberapa gigi sekaligus pada gigi yang biasanya tahan terhadap karies, kavitas karies berwarna putih sampai kekuningan, jaringan karies lunak, serta sering menimbulkan rasa nyeri atau dapat terjadi pembengkakan.

Tanda-tanda yang sering dijumpai pada anak yang terkena karies rampan yaitu adanya kesulitan makan karena bila mengunyah terasa nyeri atau linu, sering mengemut makanannya untuk menghindari terjadinya nyeri bila mengunyah, dan sering menangis karena adanya rasa nyeri yang mengenai seluruh gigi. ${ }^{2}$

Karies rampan merupakan penyakit multifaktorial karena mencakup beberapa 
faktor yang memengaruhi terjadinya karies. Karies rampan ini terjadi karena ketidakseimbangan mineralisasi dalam waktu lama di dalam rongga mulut yang diakibatkan peningkatan konsumsi karbohidrat yaitu sering mengonsumsi makanan dan minuman kariogenik yang tinggi kandungan sukrosanya. Karies rampan ini sering ditemukan pada anak usia di bawah 5 tahun dengan penyebaran tertinggi pada anak usia 4 tahun dimana pada usia tersebut gigi anak msih rentan terhadap asam dan anak belum tahu mmbersihkan gigi geliginya sendiri. ${ }^{3}$

Penatalaksanaan karies rampan pada anak bergantung pada faktor etiologi, sikap, dan motivasi orang tua dan anak dalam mendapatkan perawatan gigi, usia, serta tingkat kerja sama anak. Perawatan awal berupa tindakan pencegahan berkembangnya karies rampan harus dilakukan sebelum dimulai perawatan yang meyeluruh karena hal ini sangat menentukan keberhasilan perawatan secara keseluruhan. ${ }^{4}$

\section{DEFINISI KARIES RAMPAN}

Karies rampan adalah lesi karies yang terjadi cepat, menyebar secara luas dan menyeluruh sehingga cepat mengenai pulpa. Karies ini mengenai beberapa gigi, termasuk gigi yang biasanya bebas karies yaitu gigi anterior bawah, dan banyak dijumpai pada gigi sulung anak karena mengonsumsi makanan dan minuman kariogenik atau pada anak balita yang sering mengudap makanan kariogenik di antara makanan utamanya., ${ }^{3,5}$ Karies rampan juga merupakan lesi akut yang meliputi sebagian atau semua gigi yang telah erupsi, menghancurkan jaringan mahkota gigi dengan cepat termasuk permukaan yang biasanya imun terhadap karies, serta mengakibatkan terkenanya pulpa. ${ }^{1}$

Karies rampan yang spesifik ialah baby bottle caries. Terdapat pada anak-anak yang berhubungan dengan riwayat masa bayi, misalnya tertidur dengan botol susu masih di dalam rongga mulut yang berisi sirup atau jus (mengandung gula), pemberian air susu ibu dengan periode lama, atau memakai dot kosong yang dicelupkan dalam madu, sirup, atau gula. Frekuensi makanan karbohidrat yang tinggi pada anak dengan kebiasaan tidur minum susu botol merupakan penyebab utama dari penularan bakteri kariogenik ${ }^{6}$

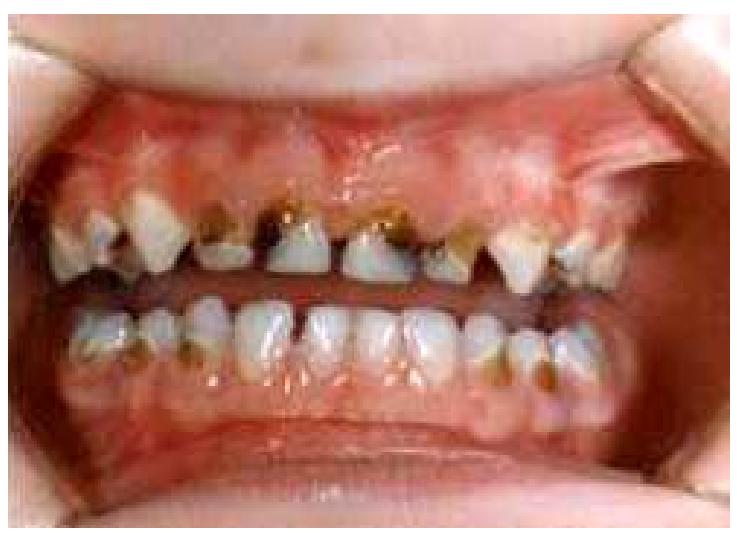

Gambar 1. Karies rampan pada anak (early childhood caries, ECC). Sumber: Ivo A, 2013.

\section{ETIOLOGI}

Terdapat berbagai faktor penyebab karies rampan, tetapi faktor utama ialah sering mengonsumsi makanan dan minuman kariogenik dengan kandungan sukrosa sangat tinggi. Sukrosa dapat diragikan oleh bakteri tertentu dan membentuk asam sehingga $\mathrm{pH}$ plak akan menurun sampai di bawah 5 dalam tempo 1-3 menit. Penurunan $\mathrm{pH}$ yang berulang-ulang dalam waktu tertentu akan mengakibatkan demineralisasi permukaan gigi yang rentan dan proses karies rampan dimulai. ${ }^{9}$

Karies merupakan suatu penyakit multifaktorial karena mencakup empat faktor yang memengaruhi, yaitu: faktor gigi, mikroorganisme (bakteri), substrat, dan waktu. ${ }^{8,10,11}$ Umumnya karies rampan terjadi karena dipengaruhi oleh keempat faktor penyebab karies yang utama, namun terdapat juga beberapa faktor penunjang karies rampan, yaitu: kebersihan mulut, faktor psikologis, faktor sistemik, dan faktor herediter. ${ }^{1,4,12,13}$

Karies rampan sering menimbulkan masalah dan yang tersering dialami oleh 
anak yaitu adanya rasa nyeri. Kesulitan makan dapat menyebabkan asupan nutrisi yang kurang. Adanya kavitas akibatnya terjadinya karies merupakan tempat tumbuh suburnya bakteri. Berbagai macam bakteri akan berkumpul sehingga merupakan fokus infeksi untuk bagian tubuh lainya. Selain itu, akibat karies rampan mulut berbau tidak enak karena adanya plak dan debris makanan yang ditumbuhi bakteri. $^{2}$

\section{PENCEGAHAN KARIES RAMPAN}

Pencegahan karies rampan harus dilakukan secepatnya ketika gigi susu anak telah erupsi yang dapat dilakukan dengan dua cara, yaitu menurut Syaifudin ${ }^{9}$ dan Rohaeni ${ }^{8}$.

\section{Pencegahan karies rampan menurut Syaifudin ${ }^{9}$}

1. Setelah diberi makan, bersihkan gusi anak dengan kain atau lap bersih. Bersihkan atau sikat gigi anak jika giginya sudah erupsi. Bersihkan dan pijat gusi pada area yang ompong dan mulai flossing semua gigi anak yang telah erupsi, biasanya pada usia 2-2,5 tahun.

2. Jangan membiarkan anak tertidur sambil minum melalui botol yang berisi susu formula atau jus buah atau larutan yang manis.

3. Jika anak membutuhkan dot untuk pemberian makan yang regular pada malam hari atau hingga tertidur, berilah anak dot bersih yang direkomendasikan oleh dokter gigi atau dokter anak. Jangan pernah memasukkan dot dengan minuman yang manis.

4. Jika air yang diberikan kepada anak tidak mengandung fluoride, tanyakan dokter gigi apa yang sebaiknya diberikan pada anak.

5. Mulai berkunjung ke dokter gigi sejak tahun pertama kelahiran secara teratur. Jika anak mempunyai masalah dengan giginya, segera periksakan ke dokter gigi.

\section{Pencegahan karies menurut Rohaeni ${ }^{8}$}

1. Pemilihan diet: Diet adalah makanan dan minuman yang dikonsumsi seharihari oleh individu. Diet merupakan salah satu faktor utama permulaan perkembangan karies sehingga pemilihan diet penting untuk diperhatikan. Orang tua terutama ibu harus mencatat kuantitas dan kualitas makanan dan minuman yang dikonsumsi anak sewaktu dan diantara jam makan. Diet vitamin dalam bentuk suplemen dan obat mulut juga harus dicatat. Orang tua dianjurkan untuk mengurangi frekuensi gula bagi anakanak terutama diantara jam makan., ${ }^{1,4}$

2. Instruksi kebersihan mulut: Perawatan gigi anak sejak dini sangat penting untuk menghidari proses kerusakan gigi, seperti karies rampan. Salah satu upaya dapat dilakukan agar dapat menghindari terjadinya karies rampan yaitu menjaga kebersihan mulut. Cara paling mudah dan umum dilakukan ialah dengan menyikat gigi secara teratur dan benar; hal tersebut merupakan usulan yang dapat dilakukan secara pribadi. ${ }^{14-16}$

3. Perawatan dengan fluor: Fluor diperoleh dari alam atau dari bentuk sediaan. Sumber fluor alami yaitu air sumur, air kali, garam, ikan, dll. Dalam bidang kedokteran gigi, penggunaan fluor untuk pencegahan karies yaitu penggunaan secara local dan sistemik. Fluor masuk secara oral sehingga mempunyai efek topikal pada gigi. Penggunaan fluor secara sistemik yaitu untuk mencapai permukaan email melalui proses pencernaan. Cara ini berefek sejak saat sebelum erupsi dan sesudah erupsi. Penggunaannya melalui air minum (PAM), tablet, dan obat tetes ${ }^{.1,4}$

American Dental Association (ADA) merekomendasikan dosis penambahan fluor bagi anak-anak dalam beberapa tingkatan usia, sesuai dengan level fluor yang terdapat pada air minum (Tabel 1). ${ }^{1,4,18}$ 


\section{PERAWATAN KARIES RAMPAN}

Tindakan yang dilakukan pada kunjungan pertama ialah menghilangkan rasa nyeri yang dapat dilakukan penumpatan sementara dengan obat-obatan yang diberikan pada kavitas. ${ }^{1,2}$

Pemberian obat dapat dilakukan secara lokal maupun oral. Pemberian obat secara lokal dilakukan langsung dengan zinc oxide eugenol, sedangkan pemberian secara oral yaitu obat-obatan sedativa dan analgesik. Obat ini diberikan terutama pada nyeri yang telah lanjut, dan bermanfaat untuk mencegah pertumbuhan bakteri penyebab karies. Bila rasa nyeri telah hilang, maka perawatan dapat dilanjutkan.,

Dalam pengendalian karies, perawatan karies rampan harus dilakukan secara sistematis dan komprehensif serta sesuai dengan prinsip pencegahan dan perawatan secara menyeluruh. Hal selanjutnya yang dilakukan dalam perawatan ialah mengurangi aktivitas bakteri untuk menhentikan karies, dan mencegah penjalaran yang cepat ke arah pulpa untuk mengurangi perkembangbiakan bakteri serta adanya bau mulut. Juga perlu dilakukan oral profilaksis dengan cara menyikat gigi secara benar dan teratur. ${ }^{2}$

Dalam melakukan perawatan perlu diperhatikan penanggulangan tingkah laku anak yang memang memerlukan keahlian tersendiri. Pada prinsipnya penanggulangan tingkah laku dapat dilakukan dengan melakukan pendekatan yang bersahabat sehingga tidak terkesan bahwa dokter gigi itu akan menyakiti. ${ }^{19}$ Dalam melakukan perawatan khusus pada penderita karies rampan yang umumnya masih sangat muda, harus dihindarkan kesan nyeri. Bila melakukan perawatan pilih pertama yang tidak menyakitkan atau bahkan yang dapat menyenangkan hati anak. Perawatan harus sesingkat mungkin agar anak tidak bosan. Selain itu pula perlu dipersiapkan teknik atau cara untuk meningkatkan motivasi anak selama perawatan. ${ }^{2}$

Tabel 1. Pemberian fluor pada anak ${ }^{1,4}$

\begin{tabular}{cccc}
\hline Usia & \multicolumn{3}{c}{ Konsentrasi fluoride dalam air minum (ppmF) } \\
& $<0,3 \mathrm{ppm}$ & $0,3-0,6 \mathrm{ppm}$ & $>0,6 \mathrm{ppm}$ \\
\hline Kelahiran -6 bulan & 0 & 0 & 0 \\
6 bulan -3 tahun & $0,25 \mathrm{mg}$ & 0 & 0 \\
$3-6$ tahun & $0,5 \mathrm{mg}$ & $0,25 \mathrm{mg}$ & 0 \\
$6-16$ tahun & $1,0 \mathrm{mg}$ & $0,5 \mathrm{mg}$ & 0 \\
\hline
\end{tabular}

Sumber:

Meskin LH, editor. Caries diagnosis and risk assessment: a review of preventive strategies and management. J Am Dent Assoc 1995;126(suppl):1S-24S.

American Academy of Pediatric Dentistry. Special issue: reference mannual 1994-95. Pediatr Dent 1995;16(special issue):1-96.

American Academy of Pediatrics Committee on Nutrition. Fluride supplementation for children: interim policy recommendations. Pediatrics 1995;95:777.

\section{BAHASAN}

Tindakan pencegahan dan perawatan karies rampan dilakukan untuk mencegah terinfeksinya gigi anak dari bakteri kariostat pada saat anak mengonsumsi makanan kariogenik yang tinggi kandungan sukrosanya. Dari beberapa artikel penelitian, penyebaran karies di setiap negara berbeda yaitu penyebaran karies tertinggi terdapat di Asia dan Amerika Serikat. Di Amerika Serikat karies gigi merupakan penyakit yang diderita oleh anak-anak karena sering mengonsumsi makanan kariogenik. Penelitian yang lain melaporkan bahwa indeks karies DEF-T pada anak usia 1 tahun sebesar 0,37\%, usia 2 tahun 2,77\%, usia 3 tahun sebesar 6,25\%, dan usia 4 tahun sebesar 9,52\%. Dari datadata tersebut hampir sepenuhnya karies 
rampan, serta ditemukan aktivitas bakteri kariostat yang tinggi. Bila tidak segera ditanggulangi karies ini akan meningkat sesuai dengan bertambah usia anak. ${ }^{2}$

Menurut Rohaeni, pencegahan karies rampan dilakukan bila gigi susu anak telah erupsi agar diperoleh suatu kesehatan gigi dan mulut yang optimal dengan cara memperhatikan diet makanan anak yaitu mengurangi konsumsi makanan kariogenik yang merupakan penyebab utama terjadinya karies rampan. ${ }^{8}$

Tindakan perawatan karies rampan dilakukan untuk mencegah penyakit berkembang hingga tidak terjadi infeksi pada gigi dan jaringan lain yang akan menimbulkan nyeri, rasa tidak nyaman, kekurangan fungsi gigi, serta mencegah maloklusi. ${ }^{1}$

Menurut Heriandi, ${ }^{3}$ pada anak yang terkena karies rampan dan sudah tidak dapat dilakukan perawatan, harus dilakukan pencabutan. Hal ini berguna untuk menghindari fokus infeksi yang ditimbulkan pada kavitas maupun abses.

Dari hal-hal yang dipaparkan di atas dapat disimpulkan bahwa setiap perawatan karies rampan memerlukan penanganan khusus karena jenis perawatan dibedakan berdasarkan kedalaman karies, dan letak karies (gigi anterior atau gigi posterior). Dalam melakukan perawatan pada karies rampan, sebaiknya dikonsultasikan terlebih dahulu dengan dokter gigi. ${ }^{2}$

\section{SIMPULAN}

Pencegahan karies rampan dilakukan bila gigi anak telah erupsi dengan memperhatikan diet, instruksi kebersihan mulut, dan pemberian fluor.

Penanggulangan karies rampan yang utama ialah menghilangkan rasa nyeri, menanggulangi penyebabnya, serta memperbaiki kesehatan gigi dan mulut anak disamping meningkatkan pencegahan dan perawatan.

Perawatan karies rampan mengacu pada penghilangan bagian gigi yang rusak, yaitu dengan penumpatan yang diberikan pada kavitas dengan menggunakan bahan- bahan tumpatan yang sesuai dengan kedalaman dan letak karies (gigi anterior atau posterior). Keberhasilan perawatan karies rampan bergantung pada koordinasi tim antara dokter gigi, orang tua, dan anak.

\section{SARAN}

Perlu dilakukan penyuluhan kepada orang tua agar menambah pengetahuan dan kesadarannya mengenai pola makan yang tepat bagi anak, dan pentingnya menjaga kebersihan mulut agar terhindar dari karies rampan. Dianjurkan kepada orang tua untuk memeriksakan kesehatan gigi anaknya ke dokter gigi setiap 6 bulan.

\section{DAFTAR PUSTAKA}

1. Radifah S. Hubungan sikap dan pengetahuan masyarakat tentang pencabutan gigi di kabupaten Bone [Skripsi]. Makassar: FKG Unhas, 2004

2. Siahaan RA. Masalah karies rampan, pencegahan dan perawatannya [Skripsi]. Medan: Universitas Sumatera Utara, 2002.

3. Heriandi S. Penanggulangan karies rampan serta keluhannya pada anak. Jurnal Kedokteran Gigi Universitas Indonesia. 2000;9(1):5-8.

4. Rosnawi Y. Hubungan antara pemberian minuman botol yang ditambahkan gula dengan karies rampan pada anak balita di Kotamadya Medan. Dentika Jurnal Ilmiah Kedokteran Gigi USU. 2000; 5(2);102-6.

5. Yiu CKY, Wei SHY. Management of rampant caries in children. Quintessence Int. 1992;23(3):159-68

6. Sumawinata N. Senarai Istilah Kedokteran Gigi. Jakarta: Penerbit buku kedokteran EGC, 2003.

7. Ivo A. Early childhood caries (ECC). [serial online]. [2013 agustus 15]. [cited 2015 Feb 26]. Available from URL: http://repository.usu.ac.id/bitstream/123 456789/8602/1/09E00832.pdf.

8. Rohaeni A. Rampan Karies [online] 2009 [cited Juli 28]. Available from URL: http=//anieroha.blogspot.com.

9. Syaifudin R. Meminum susu mnggunakan botol menyebabkan karies yang parah pada anak. [online] 2008 [cited 2009 
Juli 26]. Available from URL: http//sahipsyari fibawean.blogspot.com.

10. Wikipedia. Karies gigi. [online] [cited 2010 Juli 12]. Available from URL: http//id.wikipedia.org/wiki/karies gigi.

11. Bafira R. Pengetahuan dan praktek ibu hubungannya dengan frekuensi konsumsi makanan jajan kariogenik dan status karies gigi pada usia 2-4 tahun di Keluharan Tegasari Kecamatan Candisari Kota Semarang. [online] 2008 [cited 2010 Juli 12]. Available from URL: http//metodepenelitian. blogspot.com.

12. Fejerskov O, Kidd EAM. Dental Caries, the disease and its clinical management. London: Blackwell Munksgaar, 2003.

13. Boedi OR. Immunologi oral kelainan di dalam rongga mulut (Skripsi). Jakarta: Fakultas Kedokteran Universitas Indonesia, 2002.

14. Suwelo IS. Karies Gigi Pada Anak Dengan Berbagai Faktor Etiologi. Kajian pada anak usia prasekolah (Edisi 2). Jakarta. EGC. 2000.

15. Riani D, Sarasati. Peranan pola waktu makan terhadap karies gigi pada anak. Jurnal PDGI. 2005;1:14-6.

16. Siska DH. Pentingnya kesehatan gigi dan mulut anak. [online] [cited 2009 Aug 08]. Available from URL: http=//heryaman.kesehatan-gigi-danmulut-anak.com.

17. British Dental Association. Rampant caries in the primary dentition. [online 2009 June] [cited 2009 Sept 22]. Available from URL: http:www.bda.dentistry.org. uk/factfile./ntml.

18. Berkovits RJ. Textbook of Pediatric Care Prevention of Dental Caries. [online 2009] [cited 2009 Aug 19]. Available from URL: http://www.pediatriccare online.org/pco/chapter33.com

19. Tarigan R. Kesehatan Gigi dan Mulut (Edisi 2). Jakarta: EGC, 2005. 